\title{
LA DIVINIZACIÓN DE LA SOCIEDAD
}

DOI: https://doi.org/10.52039/seminarios.v64i224.44

JAVIER ELZO IMAZ*

La lectura del excepcional libro de Roberto Calasso La actualidad innombrable ${ }^{1}$ me ha sugerido muchas de las reflexiones que aparecen en este artículo. Me centro en una idea que me sirve de título: «la divinización de la sociedad", y que se deduce de haber suprimido el elemento religioso en la cosmovisión de nuestra sociedad. De entrada, esto me llevará, de la mano de una cita de Calasso, a un libro central de Émile Durkheim, Las formas elementales de la vida religiosa, ensayo que releo casi cincuenta años después de mis tiempos de estudiante en Lovaina. El núcleo de mis comentarios a Calasso residirá en la eterna disputa entre una visión autónoma (con su ética correspondiente) de la realidad y una visión heterónoma y trascendente de la misma. En otras palabras, entre el mundo secular y el mundo religioso, que muchos, incluido el propio Calasso -si le he entendido bien-, perciben como dos mundos perfectamente diferenciados, tesis que pondré en duda aquí.

También tendré en cuenta el libro de Salvador Giner El porvenir de la religión y su apuesta por una sociedad laica que, superadora de la sociedad religiosa trascendente, presenta como modelo de una cosmovisión superior.

Tras anotar telegráficamente los temas que aborda Calasso -en los que no voy a detenerme para no convertir este artículo en un libro-, expondré algunas reflexiones propias para cerrar, que no concluir, estas páginas.

\section{INTRODUCCIÓN: DURKHEIM Y LA SOCIEDAD DIVINIZADA}

Calasso, en las primeras páginas de su trabajo, tras recordar tiempos no tan lejanos, en los que «bastaba con divinizar al emperador para asegurar la cohesión social», añade: «Ya no. Ahora es necesario divinizar a la sociedad misma», pues, como dice Durkheim, «ella (la sociedad) es para sus miembros lo que un dios es para sus fieles» (p. 27). Así nace, en la era moderna, la «sociedad divinizada».

* Catedrático emérito de Sociología (Universidad de Deusto).

1. R. Calasso, La actualidad innombrable, Barcelona 2018. 
La referencia a Durkheim -a quien muchos sociólogos consideran, junto con Max Weber, uno de los padres de la sociología de la religión, si no de la sociología sin más- me ha retrotraído a mis tiempos de estudiante y a la lectura compulsiva de las 638 páginas (las devoré en una semana, aunque, obviamente, sin asimilarlas por completo) de una sus obras magnas, Les formes élémentaires de la vie religieuse ${ }^{2}$, donde se encuentran las palabras que cita Calasso. He localizado en mi ejemplar del libro de Durkheim dicha referencia, que transcribo a continuación más extensamente que como hace Calasso, para contextualizarla:

De manera general, no hay duda de que una sociedad tiene todo lo que se necesita para despertar en las mentes, por la única acción que ejerce sobre ellas, la sensación de lo divino; porque la sociedad es para sus miembros lo que un dios es para sus fieles. Un dios, de hecho, es antes que nada un ser que el hombre representa, en cierto modo, como superior a sí mismo y del que él cree que depende. Ya sea una personalidad consciente, como Zeus o Yahvé, o fuerzas abstractas como las que están en juego en el totemismo, el creyente, en ambos casos, se siente ligado a ciertos modos de acción impuestos por la naturaleza del principio sagrado con el que se siente en relación comercial. Pero la sociedad también mantiene en nosotros la sensación de una dependencia perpetua. Debido a que tiene una naturaleza propia, diferente de nuestra naturaleza individual, persigue fines que también son especiales para ella, pero como solo puede alcanzarlos a través de nosotros, busca imperiosamente nuestra ayuda. La sociedad exige que, olvidando nuestros intereses, nos hagamos sus servidores, y nos obliga a toda suerte de incomodidades, privaciones y sacrificios, sin los cuales la vida social sería imposible. Por lo tanto, en todo momento estamos obligados a someternos a reglas de conducta y pensamiento que no hemos construido ni deseado, y que a veces son contrarias a nuestras inclinaciones e instintos más fundamentales ${ }^{3}$.

El texto, soberbio, me sugiere los siguientes subrayados (alimentados por otros textos del propio Durkheim):

- La sociedad es más que la suma de individuos. Así como la conciencia colectiva es más que la suma de conciencias individuales.

- La sociedad tiene entidad propia, aunque no es independiente de las personas que la componen; bien al contrario, necesita de las personas para alcanzar sus fines. Hay un "comercio», dirá Durkheim, entre la sociedad y las personas que la componen.

2. El libro se publicó en 1912. En mi biblioteca he encontrado la edición de 1968, que leí y anoté en Lovaina en mis años de estudiante y es la que utilizo en este artículo. Por supuesto, hay edición castellana de esta obra magna de la sociología: Las formas elementales de la vida religiosa, Madrid 1983. No obstante, las citas que incluyo en estas páginas las he traducido personalmente.

3. E. Durkheim, Les formes élémentaires de la vie religieuse, Paris 1968, 295-296. 
-Esa sociedad crea un dios que, «de hecho, es antes que nada un ser que el hombre representa, en cierta manera, como superior a sí mismo y del que él cree que depende».

- La sociedad tiene capacidad de coerción sobre los individuos, a partir del momento en que la divinizamos.

-Esto es independiente de que el dios sea una figura concreta (Zeus o el Dios bíblico, Yahvé), sean fuerzas más o menos abstractas (tótem o las fuerzas de la naturaleza), sea la sociedad como entidad propia.

- La religión, para Durkheim, tiene como objeto crear o mantener cierta cohesión social. Que se haga por el tótem, el temor a la naturaleza, los dioses de la antigüedad o la sociedad de nuestros días, lo esencial no es la verdad de los dioses, sino la función que cumplen.

-Llegados a este punto, la pregunta que brutalmente se plantea es la de saber si salimos ganando con los dioses totémicos, o con los dioses personalizados (uno o varios, de los judíos, persas, griegos, romanos, musulmanes, cristianos, etc.), o con el dios de la sociedad, con la sociedad-dios.

Pero avancemos en la lectura de Durkheim y en lo que supone la divinización de la sociedad. Ya en las conclusiones de su estudio, nuestro autor escribe: «El ideal colectivo que la religión expresa no es consecuencia de no se sabe bien qué poder innato del individuo, pues es en la escuela de la vida colectiva donde el individuo ha aprendido a idealizar. Es asimilando los ideales elaborados por la sociedad como el individuo es capaz de concebir el ideal. Pues es la sociedad... la que le ha contraído la necesidad de alzarse por encima del mundo de la experiencia» (p. 604). Así, para Durkheim está claro el papel de la sociedad como agente primordial de creación de cosmovisiones, como agente de socialización, como instancia de lo políticamente correcto, de lo obvio, de lo indiscutible, de las certezas indiscutibles.

Claro que, encarnándose en cada individuo los ideales colectivos, estos tienden a individualizarse. Pero -insiste fuertemente en ello Durkheim- el ideal personal, aun individualizado, proviene del ideal social, de la conciencia colectiva que en cada momento conforma una sociedad determinada. Esto es particularmente cierto, según él, en el caso de la fe religiosa. En la página 607, luego ya avanzado en las conclusiones de su ensayo, podemos leer algo que ya me llamó la atención en mi primera lectura en Lovaina el año 1970, pues lo subrayé. Escribe Durkheim que «una filosofía puede elaborarse en el silencio de la meditación interior, pero no una fe». Para él, pensar en un individualismo radical que hiciera de la religión algo puramente individual supone desconocer las condiciones fundamentales de la vida religiosa, y estas provienen de la sociedad de nuestros semejantes: «Las 
fuerzas morales en las que podemos sustentar y crecer las nuestras son las que nos prestan otros», de la misma forma que «las creencias solamente son activas cuando son participadas». Todo esto nos muestra la importancia capital que Durkheim concede a la sociedad como tal, y más precisamente a la conciencia colectiva que la sociedad tenga de sí misma.

Ahora bien, ¿cuál puede ser el tenor de esa conciencia colectiva? ¿Dependerá de las condiciones materiales que presidan, en cada momento, la sociedad en cuestión? Sin negar la importancia de estas condiciones materiales, Durkheim se separa de una interpretación meramente materialista de la historia. Aquí la cita se impone: «Hay que rechazar que mi teoría de la religión sea como un rejuvenecimiento del materialismo histórico: pensar así supondría equivocarse singularmente sobre nuestro pensamiento. Mostrando que la religión es una cosa esencialmente social, no entendemos de ninguna de las maneras que la religión se limite a traducir, en otro lenguaje, las formas materiales de la sociedad y sus necesidades vitales inmediatas... Pues la conciencia colectiva es otra cosa que un simple epifenómeno de su base morfológica, así como la conciencia individual es otra cosa que una simple eflorescencia del sistema nervioso. Para que la primera aparezca se precisa una síntesis sui generis de las conciencias particulares». Y a renglón seguido Durkheim nos muestra, con rotundidad, la independencia de la conciencia colectiva respecto de las condiciones materiales de origen y de las conciencias individuales, así como su gran poder de coerción: «Esa síntesis (que da lugar a la conciencia colectiva) tiene el efecto de liberar todo un mundo de sentimientos, de ideas, de imágenes que, una vez hayan nacido, obedecen a leyes que le son propias. Se llaman, se repelen, se fusionan, se segmentan, proliferan sin que todas esas combinaciones sean directamente comandadas y necesitadas por el estado de la realidad subyacente. La vida así suscitada goza, incluso, de una independencia bastante grande, originando a veces manifestaciones sin objetivo concreto, sin utilidad alguna, simplemente por el solo placer de afirmarse» (p. 603). En otras palabras, la sociedad se presenta, para Durkheim, como el agente fundante de cosmovisiones, como agente básico de socialización, como instancia de lo políticamente correcto, de lo obvio, de lo indiscutible, de las certezas indiscutibles.

En conclusión, frente a la sociedad estamos ante un dios absoluto, aunque necesitado en su origen y después en su actuar de los humanos. Es un dios todopoderoso, arbitrario, omnisciente, juez de los hombres (y mujeres, claro), pero que necesita de esos hombres y mujeres para ejercer su divinidad, pues de ellos proviene. Durkheim no entra a discutir si hay una realidad divina, más allá de la humana, si esa realidad es un tótem o un dios personal, o una realidad abstracta, pero sí reconoce, y de qué manera, su autoridad 
para sus «creyentes», sus «fieles» (los humanos), una vez originados por la conciencia colectiva de la sociedad considerada, que así adviene, origen de la divinidad que, a su vez, deviene controladora de esa misma sociedad. Insisto, poco importa la forma que adopte esa divinidad, pero eliminados o considerados rémoras del pasado los dioses de las religiones de antaño, sean animistas, naturalistas o personales (unipersonales como los monoteísmos -Yahvé, Jesús el Cristo, Alá-, o colectivos -los politeísmos-), solo queda la propia sociedad que se eleva así a la condición de divinidad todopoderosa.

Detengámonos un poco en las características de esta sociedad, siguiendo todavía la reflexión de Durkheim, ya en las páginas finales de su publicación. Calasso subraya estas palabras del sociólogo francés para definir la sociedad, tal y como este último la ve: «En resumen, la sociedad no es de ningún modo el ser ilógico o alógico, incoherente y fantástico que algunos gustan muy a menudo de ver en ella. Todo lo contrario, la conciencia colectiva es la forma más alta de la vida psíquica, ya que es una conciencia de conciencias. Colocada fuera y por encima de las contingencias individuales y locales, solo ve las cosas en su aspecto permanente y esencial, que ella fija en nociones comunicables. Al mismo tiempo que ve desde arriba, ve a lo lejos: en cada momento del tiempo abraza toda la realidad conocida; por eso solo ella puede suministrar al espíritu las clasificaciones que se aplican a la totalidad de los seres y que permiten pensarlos» ${ }^{4}$.

Calasso comenta estas líneas afirmando que «se diría que aquí habla un presocrático a propósito del logos. En cambio, se trata del fundador de esa 'triste ciencia': la sociología». Aunque Durkheim atribuye esa condición de fundador a Saint-Simon, Calasso dice de ellos dos -Saint-Simon y Durkheim- que «no eran tan solo estudiosos y analistas de algo denominado sociedad; eran los primeros sacerdotes -más lúcidos y consecuentes que los otros, que se detenían a medio camino- de un nuevo culto: el culto a la sociedad divinizada» ${ }^{5}$.

En definitiva, la independencia, autonomía y capacidad de coerción de la conciencia colectiva de una sociedad concreta, una vez constituida, adquieren así, para Durkheim (y lo corrobora Calasso), los rasgos de una divinidad que, aunque creada por una síntesis de las conciencias particulares, se im-

4. E. Durkheim, Les formes élémentaires, 633-634, que cita Calasso en 27-28.

5. R. Calasso, La actualidad innombrable, 27. Al sociólogo que es uno, amén de chirriarle el epíteto de «triste» aplicado a su disciplina, no deja de confirmarle en lo que debe ser el trabajo del sociólogo: un «analista de la sociedad», quizás más precisamente "un analista de las relaciones sociales», sin que vea en ello ningún sacerdocio, pues no participa el sociólogo, como tal, de ninguna religión, fe o Iglesia. Otra cosa es que, como persona, tenga sus convicciones. Así, habrá personas que sean, al mismo tiempo, sociólogas y ateas, sociólogas y agnósticas, sociólogas y cristianas, sociólogas y musulmanas... 
pone a estas con poder coercitivo. Falta por explicar (lo que no haremos en estas páginas) cómo se crean determinadas ideas en la conciencia colectiva, estas y no aquellas ideas que pretenden imponerse sobre las conciencias particulares. Asimismo, qué función persiguen, aunque parece que, en el caso de las ideas religiosas, según Durkheim, pretenderían lograr o preservar la cohesión de una sociedad. En efecto, la divinización de la sociedad nos lleva a pensar que esa, precisamente esa, sería la pretendida función del dios-sociedad. Pero ¿lo logra? Difícil responder afirmativamente, dado el pluralismo reinante. Nosotros nos inclinamos a pensar que la divinización de la sociedad, tras la exculturación social de lo religioso en general y de los dioses religiosos en particular, en realidad nos lleva, en el actual mundo secular, a una nueva "guerra de dioses». Pero, de entrada, debemos plantearnos la cuestión de saber qué consecuencias tiene para nosotros, ciudadanos de las dos primeras décadas del siglo XXI, el hecho de que hayamos delegado en la sociedad, divinizándola, el sistema de legitimación de las relaciones sociales, de los valores dominantes que nos dicen lo que es bueno y lo que es malo, y cuáles son las prioridades por las que debemos esforzarnos en mantener, al menos, un simulacro de cohesión social. No otro es el nudo gordiano -si lo he entendido bien- que pretende desatar la reflexión de Calasso, tras constatar la sociedad divinizada en la que nos encontramos.

\section{LA IMPLANTACIÓN TRIUNFAL DE LA SOCIEDAD SECULAR EN EL SIGLO XX}

Aunque el tema se presta a mil y una reflexiones y debates ${ }^{6}$, hay un constructo social dominante en el mundo occidental, particularmente en el del sur de Europa, en señalar que el mundo secular ya ha vencido al mundo religioso que aparece en la conciencia colectiva, particularmente la del progresismo en punta, como una entelequia del pasado, a punto de desaparecer, al fin, definitivamente. Así, casi al inicio de su trabajo Calasso escribe: «La sociedad secular, sin necesidad de proclamas, se convirtió en el siglo XX en el último cuadro de referencia para todo significado. La búsqueda de significados debiera limitarse al seno de la propia sociedad. Esta puede asumir las formas políticas y económicas más diversas, capitalistas o socialistas, democráticas o dictatoriales, proteccionistas o liberales, militares o sectarias. Todas deben considerarse, en cualquier caso, como meras variantes de una única entidad: la sociedad en sí misma. Es como si la imaginación se

6. Nos permitimos remitir a los dos primeros capítulos de nuestra publicación Morir para renacer, Madrid 2017, donde abordamos con detalle esta cuestión, en diálogo con relevantes sociólogos del denominado proceso de secularización, particularmente Peter Berger. 
hubiera amputado a sí misma, después de miles de años, su capacidad de mirar más allá de la sociedad, a la búsqueda de algo que diera significado a lo que sucede en el interior de la sociedad» (p. 21s).

La sociedad secular sería esa que no cree en nada que esté mas allá de sí misma, de suerte que ha renunciado a toda creencia y se limita a observar, estudiar, analizar lo que sucede alrededor. Y lo hace con la buena conciencia de lo que en el pasado sucedía cuando, en razón de determinadas creencias, particularmente religiosas, se vivían las precisamente denominadas «guerras de religión» en choques motivados, más que por creencias religiosas, por las diferentes creencias en las que se basaban los poderes políticos para justificarse o asentarse en su poder. Este argumentario está muy en boga en nuestros días, conformando uno de los pilares de la conciencia colectiva por utilizar la terminología durkheimiana. Aunque no es difícil recordar que el siglo XX vivió dos terroríficas guerras, donde la dimensión religiosa apenas fue importante, y, en la segunda, con dos líderes, Stalin y Hitler, que en nada cabe definir como líderes de religiones religiosas. Pero no es menos cierto que, en España, una rebelión militar fue tildada de cruzada.

En todo caso, ya avanzado el siglo XXI cabe decir con Calasso que «si lo esencial no es creer sino conocer, como presupone toda gnosis, se tratará de abrir un camino en la oscuridad, usando todos los medios, en una suerte de incesante bricolaje del conocimiento, sin tener ninguna certeza acerca de un punto de inicio y sin siquiera figurarse un punto de llegada». Y añade: «Esta es la condición, a la vez mísera y apasionante, en la que se encuentra quien hoy no pertenece a alguna confesión pero al mismo tiempo se niega a aceptar la religión - 0 , más precisamente, superstición- de la sociedad» (p. 29). Es la condición del homo saecularis (Calasso), figura que abordaremos más adelante. Pero quiero subrayar ya dos aspectos.

El primero para recordar a Tomás de Aquino cuando decía que «no se puede creer y saber a la vez». Luego no ha hecho falta llegar a la sociedad secular de la mitad del siglo XX ni al imperio de la ciencia empírica para tener conciencia de que el ámbito de las creencias es otra cosa que el de las realidades materiales, particularmente las constatables por la experiencia científica. A lo cual cabe añadir que, salvo para los cientificistas que han hecho de la ciencia su religión, es sabido que la verdad científica es, por esencia de lo que es la ciencia, una verdad temporal y parcial.

El segundo apunte es para subrayar que la dualidad entre lo sagrado y lo profano, según muestra Peter Berger, puede y debe ser superada ${ }^{7}$. Esta cuestión me parece capital y volveremos sobre ella al final de estas páginas.

7. Remitir aquí a los dos primeros capítulos de mi libro Morir para renacer. 


\section{LA DEMOCRACIA ¿NO SERÍA SINO UN CONJUNTO DE REGLAS Y PROCEDIMIENTOS?}

Se ha vuelto celebérrima la frase de Churchill de que «la democracia es el peor de todos los sistemas políticos, con excepción de todos los sistemas políticos restantes», y no seré yo quien la discuta. Ciertamente, no veo en mi mente y menos en la realidad, un sistema político que pueda superar al democrático, lo cual no me impide notar no pocos de sus límites. Pues si aceptamos la divinización de la sociedad, hacer de la sociedad nuestro dios, habremos de convenir en que la democracia no conforma como tal un pensamiento concreto más allá de una serie de reglas y procedimientos, siempre en contante revisión. La democracia, más allá de la proclamación de que busca lo mejor y lo más justo para las personas que la componen, al final, consiste en una serie de reglas y normas que cumplir. Basta pensar en las mil y una formas de recuento del principio formal de «cada persona un voto», por ejemplo, recientemente en España con la fórmula que quisiera adoptar el líder de Ciudadanos, Albert Rivera, y parece que también el del Partido Popular, Pablo Casado (¿quién dijo que juventud equivalía a innovación?). Como escribe Calasso, «lo asombroso de la democracia consiste en su carácter vacío, carente de contenido. Es una doctrina en la cual lo esencial es la regla, antes incluso que aquello que la regla prescribe» (p. 36). En el contexto de la España actual, con el conflicto catalán encima de la mesa, líderes políticos en la cárcel o autoexilados, el actual sistema penal cada vez más duro (¡prisión permanente revisable tras treinta años de cárcel!) y el clamor en la calle por endurecerlo, por ejemplo, para casos de violencia de género, y en otros muchos aspectos, yo diría que lo esencial en la democracia española, en opinión de no pocos, es la ley, la ley por la ley, y no lo que la ley prescribe. Aunque siempre será pertinente preguntarse, también, qué leyes se cambian, qué leyes se refuerzan, qué leyes se difuminan y en qué contextos se producen esas modificaciones. Me vienen a la mente tres casos en los que se modifica la ley ad hoc: para legalizar la ilegalización de Batasuna, la prisión permanente revisable y la ley sobre la violencia de género. Tres ejemplos que nos muestran cómo se modifica la ley para acomodarla a determinados objetivos políticos o contextos sociales del momento. A determinadas fases de la conciencia colectiva, en palabras de Durkheim ${ }^{8}$.

8. Zeid Ra'ad Al-Hussein, alto comisionado para los derechos humanos de la ONU, afirma en una entrevista que «la tortura gana de nuevo una especie de admisibilidad» en la actual regresión de los derechos humanos (Le Monde, 1.8.2018). Por desgracia, España no es excepción en esta deriva de insensibilización hacia la tortura. Un ejemplo clamoroso lo tenemos en el nombramiento del magistrado Grande Marlaska como Ministro de Justicia cuando había sido llamado al orden por el Tribunal europeo de Derechos Humanos. 
Y ahí, precisamente ahí, es donde la democracia formal-pues la democracia de la que hablamos no es sino formal- tiene su talón de Aquiles, pues, como nos recuerda Calasso, «la llaga abierta de la democracia es la posibilidad de que, por vías legales, alcance el poder quien se propone abolir la democracia misma, como sucedió con Hitler en enero de 1933» (p. 34).

Es imposible no pensar ahora mismo en lo que está sucediendo no solamente en Turquía, Venezuela o Nicaragua, sino también en algunos países del este europeo, Polonia, Hungría..., y en el corazón de la Europa democrática, Holanda, Austria, Alemania, Francia, Italia, sin olvidar los pases nórdicos, donde se está viviendo el retorno de los fascismos, que ya advirtió Rob Riemen, retorno que algunos, aunque pocos, no nos cansamos de recordar ${ }^{9}$. Aunque hay que recordar, como hace Calasso, que, «en el fondo, lo que unía a Lenin y Hitler era, ante todo, la aversión por la democracia formal. Todo lo demás se deducía de ello como una consecuencia, en direcciones distintas, pero no tan lejanas, en definitiva» (p. 36).

Aunque no sea más que como un breve apunte, conviene señalar los riesgos que conlleva lo que se denomina la "democracia directa», que no es otra cosa que la democracia formal, pero sin sus mínimas formas -quórum, representatividad, voto secreto, asamblearismo, etc.-, lo cual la convierte en prima hermana de la dictadura. ¡Ay, esas asambleas en los centros educativos, con una representación que no llegaba a menudo al $5 \%$ de los estudiantes afectados, donde, tras interminables discusiones procedimentales, se votaba a mano alzada la suspensión de las clases, o cosa parecida, cuando ya se tenía la victoria asegurada!

\section{PúlPItOS LAicos. El PENSAMIENTO SECULAR Y EL «HOMO SAECULARIS»}

El mundo secular portado por el homo saecularis se impone, una vez que la dimensión religiosa deja de circular, sea porque ha sido (presuntamente) sustituida por el pensamiento secular, sea porque ha sido arrinconada en el baúl de las cosas de otro tiempo. Pero hay que preguntarse en qué consiste el pensamiento secular, si es que consiste en algo más que en retazos de pensamientos de otros tiempos, como apunta Calasso, quien, tras un quiebro por Frederic Skinner, que fue, en un principio, aceptado por la comunidad científica, al presentar el perfecto homo saecularis como sumatorio de reacciones consolidadas, hoy, sin embargo, es ya considerado «un desecho inútil».

9. Cf. R. Riemen, L'Eternel retour du fascisme, Paris 2011. Asimismo, dos artículos de Manuel Castells: «Vuelve el fascismo (1) y (2)», en La Vanguardia 30.6.2018 y 7.7.2018. 
Sí, ¿en qué consiste el pensamiento secular? Responde Calasso:

El pensamiento secular es lo que queda después de un proceso de vaciamiento progresivo que opera desde hace varios milenios. Animales, dioses -en plural y en singular-, demonios, ángeles, santos, almas, espíritus y, en fin, hasta los principios y voluntades han sido gradualmente evacuados. Se han convertido en materia de investigación. Siguen presentes, pero en los libros. En el ínterin, el pensamiento cotidiano iba prescindiendo de ellos con creciente entusiasmo. Homo saecularis habla con muchas voces a menudo divergentes. La que se hace oír principalmente es progresista y humanitaria. Aplica preceptos de herencia cristiana reblandecidos y edulcorados. Mezcla tibia y pálida, se combina, en sentido inverso, con el movimiento en curso en la propia Iglesia, que busca parecerse cada vez más a una entidad asistencial. El resultado es que los secularistas hablan con una contrición propia de eclesiásticos a la vez que los eclesiásticos quisieran hacerse pasar por profesores de sociología (p. 44).

Es difícil no reconocer la pertinencia de esta constatación, que a cualquier observador atento no pasa desapercibida. Desde hace años me sorprende comprobar cómo radios y televisiones ${ }^{10}$ se han convertido en púlpitos laicos de toda suerte de buenos propósitos acerca de mil y un necesitados y agraviados que pueblan la sociedad. A veces son minorías, como los portadores de enfermedades raras; otras, quienes manifiestan determinadas e infrecuentes atracciones sexuales (lo que no impide que tengan los mismos derechos que los demás, e incluso más, justamente por la debilidad que supone su bajo número). En algunos casos no son minoritarios, pero de pronto han adquirido fuerte relevancia social, como las mujeres (no solo por las violencias de todo tipo que padecen), los jubilados, los migrantes, sin olvidar hoy a los animales en peligro de extinción, etc. Nuestros medios de comunicación están llenos de estos contenidos humanitarios. No seré yo quien lo reproche, bien al contrario, aunque, si se me permite, apuntaré al problema de saturación, a menudo unido a un pensamiento uniformista que, en más de un caso, genera efectos contrarios a los deseados. A título de ejemplo, en determinadas manifestaciones feministas percibo sotto voce una saturación y un uniformismo que, en otros países, ya tiene réplica intelectual con otros planteamientos feministas que obviamente lo enriquecen ${ }^{11}$.

En mis lecturas de pensadores que se declaran agnósticos y en conversaciones con amigos del mismo talante, constato una idea que asoma cada vez que sale a relucir la religión cristiana: «Me quedo-dicen-con su doctrina moral de 'amaos los unos a los otros', del amor universal sin acepción de per-

10. Mientras que en la prensa escrita pueden seleccionarse las informaciones y pasar a otras, en la radio y TV solo queda cambiar de canal, donde en muchos casos se habla de lo mismo y hasta de la misma manera. Y no digamos si la noticia procede de una sola agencia.

11. Sobre este tema, Feminismo sí, pero qué feminismo, http://javierelzo.blogspot.com. 
sonas, de una religión que se pretende universal y no religión de un pueblo, etc., pero no me hagan creer en un hombre-dios, en una resurrección, en un dios trinitario, en un más allá donde nos veremos las caras al final de los tiempos...». Admiten la religión cristiana como un eslabón de la conciencia de la humanidad (al menos en Occidente) que, tras la llustración y ante el avance de la tecnología, no cabe sino limitar a su dimensión caritativa, expresión a la que preferirán la de «solidaria» o «fraterna». No faltará quien piense que, a fin de cuestas, la religión cristiana está muriendo de éxito: está en la base del humanitarismo contemporánea, pero debe renunciar, o dejar entre paréntesis, al menos en público, su trascendencia.

En consecuencia, ahora, que ya se está aceptando que el cristianismo es «la religión que ha propiciado la salida de la religión» en la organización social y política del planeta (Gauchet), puede -y debe, según algunos- limitarse a ser una de las tantas instancias críticas para la humanización de la sociedad. No veo problema alguno, más bien al contrario, en que el cristianismo en general y el catolicismo en particular sea una de las instancias críticas para la humanización de la sociedad, pero a condición de no querer reducirla a una gigantesca ONG extendida por todo el planeta que, amén de difícil gobernabilidad, se hubiera amputado de su dimensión transcendente, ocultando lo divino, limitándolo a lo sumo al culto y cultivo privado.

Pues entonces se reduciría la religión a una moral que, a la postre, parece que se convierte en humanismo, producto del pensamiento secular. Es lo que Calasso denomina el «secularismo humanista», que no sería sino una religión secular cuyo objetivo fuera la prosperidad, la justicia, el bienestar de los homínidos. He aquí una religión basada en la sociedad, en los individuos de la sociedad, quienes, convertidos en conciencia crítica, aquí y allá, por esto y por aquello (basta consultar radios y televisiones), coinciden en dejar de lado toda conciencia que no provenga de ellos mismos, pero que a la vez entienden que no son otros, sino ellos mismos los principales depredadores del mundo en construcción. Con lo que cerramos el círculo. No estaba peor la humanidad, ni tenía mejor conciencia de sí misma, después del pecado de Adán y Eva, si seguimos a Pablo de Tarso y Agustín de Hipona, aunque estos veían una salida al círculo. Y antes que ellos, ya la religión judía.

En el último libro de mi admirado amigo Arnoldo Liberman ${ }^{12}$, leo lo que representó para el gran filósofo Emmanuel Levinas la lectura atenta de la Torá o del Talmud: «La interpretación no se da, para Levinas, en la inspiración intelectual solitaria que Dios da al hombre para que éste descubra

12. A. Liberman, Heidegger y yo, judío, Madrid 2018, 52-53.51. 
en el texto bíblico la verdad; la inspiración es el momento ético, la relación con el otro, donde el Otro se manifiesta». Y citando esta vez a Rosenzweig, escribe Liberman: "La relación con lo divino atraviesa la relación con los hombres y coincide con la justicia social, tal es el espíritu de la Biblia judía». Levinas va aún más lejos al Señalar: «La idea fuerte del judaísmo consiste en transfigurar el egocentrismo o el egoísmo individual en vocación de la conciencia moral. En esa perspectiva se sitúa para el judaísmo el papel propio de Israel, su dignidad de pueblo elegido que ha sido frecuentemente ignorado. Ser el pueblo elegido no es un orgullo, no es la conciencia de derechos excepcionales, sino de deberes excepcionales. Es el atributo de la conciencia moral misma, porque soy irremplazable para asumir responsabilidades». Se pregunta a renglón seguido Arnoldo Liberman: «¿Y Dios? Para Levinas, el gobierno de Dios consiste en someter a los hombres antes a la ética que a los sacramentos». No otra cosa leemos en la Carta primera de Pablo a los corintios en su imprescindible capitulo 13. Valga este recordatorio del segundo versículo del capítulo: «Aunque tuviera el don de profecía y conociera todos los misterios y toda la ciencia; aunque tuviera plenitud de fe como para trasladar montañas, si no tengo caridad, nada soy».

\section{CUANDO EL HUMANISMO SECULAR ARRUMBA AL DE MATRIZ RELIGIOSA}

El secularismo humanista pretende haberse desembarazado de toda fe y de toda religión transcendente o meta empírica, pero sin renunciar a lo que constituye la quinta esencia de la moral cristiana, si no en su ortopraxis, sí en su ortodoxia; si no en lo mejor de su práctica los últimos veinte siglos, sí en su principio ético fundante: no solamente el bienestar de todos, dicho en lenguaje secular, sino también en su «ontología» de que a través de los otros llegamos al Otro, mostramos al Otro, o quizá más exactamente el Otro se nos muestra en los otros. De ahí, como señala Calasso, que «los secularistas puros, privados de cualquier filiación religiosa y poco inclinados a los caprichos espiritualistas, no pueden renunciar a la necesidad de sentirse buenos. Su ideal sería que algún biólogo neodarwinista demostrase que la sociedad, desde sus orígenes se funda sobre el altruismo y la tolerancia. Por eso, ser buenos constituye una ventaja evolutiva, único criterio con el que puede medirse el bien. Cada año algún voluntarioso intenta, en vano, demostrarlo» (p. 49), concluye Calasso.

Personalmente, y sin necesidad de apelar a la condición religiosa, considero que el género humano ha progresado en su dimensión ética, en el respeto a los derechos humanos, y que poco a poco, aunque en la buena dirección, se está abriendo al respeto al mundo animal y al planeta. Aun con 
altibajos, la humanidad del siglo XXI, digámoslo así, es más justa, o si se prefiere, menos injusta que hace veinte siglos, diez, cinco e incluso que el siglo pasado. El error en el que caemos, incluso cuando no se quiere caer en él, reside en: a) no reconocer el papel que la religión cristiana (pues en ella me centro en estas líneas) ha tenido en este mejoramiento de la condición humana, y b) la pretensión de una determinada superioridad del humanismo secular sobre lo que llamaré humanismo religioso, dando así la vuelta al calcetín de la historia cuando se sostenía, en el mundo cristiano, que la fe, o la trascendencia, añadían un «plus» al mundo secular.

En el fondo, de lo que se trataría sería de sustituir un humanismo religioso por otro laico. El humanismo religioso, a fin de cuentas, sería algo extravagante y extemporáneo, ilustración de los tiempos oscuros anteriores al de las Luces (la llustración, precisamente), que, ya en la era moderna, con la ciencia y, sobre todo, la alta tecnología, está llamado a desaparecer. Claro que, entre tanto, y a tenor de la universalidad de los derechos humanos (quinta esencia de la religiosidad civil), habría que respetar a los pertinaces seguidores de tal humanismo religioso (que tardan demasiado en menguar) siempre que, cual reserva india, lo profesen en la intimidad de sus mentes y sus templos. Quizá habría que acelerar su extinción con algunos discretos empujones: la moda vestimentaria de las musulmanas en Francia, la eliminación de cruces y demás símbolos religiosos en los espacios públicos en España, la sustitución del referente religioso por el laico en las enseñanzas regladas, cuestionar cualquier ayuda económica a actividades religiosas, aunque siempre habrá para los estadios de fútbol, baloncesto etc., pues se dice -falsamente- que la actividad deportiva no implica acepción de personas, como si todo el mundo vibrara con los partidos de fútbol ${ }^{13}$.

Debajo de este planteamiento se inscribe una idea que ya conforma la cosmovisión dominante en gran parte del sur de Europa y, en todo caso, en la España publicada: la supremacía del humanismo secular, no diré sobre la dimensión religiosa, sino sobre el humanismo religioso. Incluso pensadores extremadamente respetuosos con la valencia religiosa acaban sosteniendo tal planteamiento. En las páginas siguientes, aparcando el tiempo de un excursus a Calasso, lo voy a mostrar, reflexionando con una publicación de mi colega sociólogo (apreciado amigo, pese a lo poco que físicamente hemos coincidido) Salvador Giner.

13. Escribí estas líneas cuando Francia acaba de ganar el Mundial de fútbol de 2018. No puedo dejar de mencionar cómo el serio Le Monde del día siguiente a la final (16.7.2018) consagró las 16 primeras páginas de su rotativo a la «hazaña». Obviamente, este diario no fue el único. Por cierto, durante los festejos en Francia fueron detenidos unos 300 individuos por toda suerte de violencias, estas sí tumultuarias, sin que ninguno siga en la cárcel. 


\section{EXCURSUS: La apuesta por el humanismo laico de Salvador Giner}

Me detengo aquí para comentar un texto de mi apreciado colega Salvador Giner El porvenir de la religión ${ }^{14}$, como ejemplo de este modo de pensar. Giner señala, ya desde las primeras páginas, que «el humanismo de hoy no es, en sí, ciegamente hostil a la religión... La tolerancia es parte de su credo laico» (p. 38). Poco más adelante escribirá: «Reitero lo dicho sobre el potencial dañino de cualquier creencia que albergue dogmas inamovibles en su seno. De ello no se libra ni siquiera el humanismo, cuando es extremo y dogmático. Ello sería negarse a sí mismo» (p. 42). Podría multiplicar las citas en este sentido, que aplaudo a dos manos. Añado que mi aplauso no se limita al credo laico, sino también al religioso, como he escrito reiteradas veces; por ejemplo, comentando -para rechazarlo- el axioma de que «fuera de la Iglesia no hay salvación», que aún campa en el Catecismo de la Iglesia católica. Pero Giner da algunos pasos más ante los que quiero mostrar mi interrogación y mi discrepancia.

En primer lugar, cuando concede al humanismo laico una supremacía sobre el humanismo de raíz o signo religioso. He aquí un ejemplo: «Con toda sencillez, a quienes piensen que algo más grandioso, profundo y eficaz que el humanismo laico será la salvación les corresponde en puridad demostrarlo. No a quienes confían cautamente en él, así como en la ciencia, la racionalidad y la naturaleza como únicas soluciones para la superación común de nuestros males» (p. 104). Es decir, el humanismo laico no tiene nada que demostrar. Se le presupone (cuando es tolerante) no solo una bondad innata, sino además una supremacía sobre otras formas de humanismo nada menos que «para la superación común de nuestros males», incluso para «la salvación». Para ello debe basarse en «la ciencia, la racionalidad y la naturaleza». Las preguntas se me amontonan: ¿De qué salvación habla Giner? O quizá mejor: ¿De qué hecatombe nos quiere salvar mediante el humanismo laico? Las apelaciones a la ciencia, a la racionalidad y a la naturaleza, como instrumentos para lograr tal salvación, exigen una profundización por la que, estoy seguro, apostaría Giner. Pues: a) la ciencia -y eso lo sabemos bien los científicos sociales- es, por definición de ciencia, parcial en el doble sentido del término «parcial»; b) la racionalidad, atributo central de la condición humana, sin embargo, no agota su conocimiento (recuérdese a Pascal), y c) cuidado con divinizar la naturaleza. Ya sabemos los cristianos a dónde nos lleva equiparar la ley natural con la ley de Dios. La naturaleza es nuestro hábitat y debemos cuidarlo, pero la naturaleza como tal es ciega. Obedece a unas

14. S. Giner, El porvenir de la religión, Barcelona 2016. 
leyes meramente físicas. No entiendo cuando escucho que «la naturaleza es sabia». ¿Por qué semejante divinización de la naturaleza, de lo natural, que uno ve en mil y un folletos propagandísticos? Lo natural vende.

Pero quizá lo que subyace en el planteamiento de Giner y frente a lo que se insurge ( $\mathrm{y}$, a mi vez, me insurjo) es a una determinada concepción de lo religioso como algo cerrado, dogmático, incuestionable, que denomina «cepo doctrinal». Lo dice así: "A la certidumbre que acompaña a toda creencia religiosa la llamo 'cepo doctrinal'. Es el elemento de certeza en algo que se cree únicamente porque alguien investido de poder, autoridad, carisma u otra cualidad externa a nuestras conciencias y propia de la vida social nos lo ha referido. Toda religión, sin excepción, somete a sus convencidos, a sus fieles, seguidores, miembros y hasta meros simpatizantes a la servidumbre de su cepo doctrinal. No cabe aquí mucho matiz» (p. 84; la continuación de este texto muestra la rotundidad del planteamiento de Giner).

Es evidente que, para tal afirmación, encontramos innegables evidencias históricas. Acabamos de recordarlo con el aforismo de que «fuera de la Iglesia no hay salvación», y traemos aquí aquel terrorífico principio-que afortunadamente quedó tumbado al inicio del Concilio Vaticano II, aunque cual Guadiana emerge todavía con frecuencia- de que «el error no tiene derechos». La idea de pertenecer a la única Iglesia verdadera, al único credo verdadero, a la única religión verdadera ha atravesado el mundo desde el origen de los tiempos y sigue ahí presente en la actualidad. Pero, como acaba de mostrar el propio Giner, también anida, pese a sus cuidados, en la fe laicista, en el humanismo secular, que diría Calasso, y en el humanismo laico que defiende el propio Giner, como «única solución a los males de la humanidad». Lo mismo cabe decir de todos los «ismos». ¿Es que no vemos cómo el socialismo derivó en estalinismo, y tantas revoluciones en dictaduras?

Me viene a la memoria la reflexión de Peter Berger cuando habla de este modo de pensar como el único valido en una conciencia moderna, coincidiendo así con la tesis central de Calasso. Ya muy avanzado su texto, Berger escribe: «Una vez establecido el discurso secular, tanto en la mente del individuo como en la sociedad, es inevitable que se produzcan disputas respecto a los límites. Los secularistas radicales, cuya cosmovisión ha sido legitimada a nivel filosófico ya desde la llustración, negarán que exista ese problema de límites. El pensamiento racional, tal como lo entienden, supone la única forma válida de conocimiento; todo otro discurso, incluido el que está en el centro de la mayor parte de las religiones, es una superstición que ha de ser denunciada y expulsada del canon cognitivo. No hay límites que negociar porque 'el error no tiene derechos'... Un ejemplo actual de esto es el esfuerzo que algunos ateos realizan para explicar -e ipso facto para rechazar- todo 
fenómeno religioso en términos de neurología; Dios no es otra cosa más que un tic en alguna zona del cerebro humano» ${ }^{15}$.

Claro que Giner, en la anteúltima página de su libro (p. 126), tras un último aguijón a las creencias religiosas como poco favorables a la racionalidad, deja caer una carga de profundidad sobre el fundamentalismo, que él aplica al dominio religioso y que yo extiendo también al humanismo laico y al pensamiento secularista extremo. Giner, tras escribir que «el universo de las creencias religiosas, en todo caso, no es favorable a la coherencia o a la lucidez cognoscitiva», lo matiza en el mismo renglón con esta condicional: «Salvo en muy excepcionales circunstancias, en las que se estimulan o toleran ciertas dudas. En algunas, la duda ocupa un lugar crucial en su relato. No es menester recordar a los cristianos la crucial importancia que para ellos tiene la duda de san Pedro, descrita en los Evangelios, pero también la de san Agustín y la de otros grandes pensadores y místicos a lo largo de la historia». ¡Al fin!

Ciertamente los cristianos sabemos que «una fe que no duda es una fe dudosa», aunque demasiadas veces en la historia del cristianismo la duda ha sido proscrita, incluso con la tortura, pero somos muchos los que dudamos -así el propio papa Francisco, que ha reconocido, con su habitual bonhomía, que él también duda cuatro veces al día, y quien esto suscribe, cuando, comentando el trabajo de Peter Berger recién mentado, titulé el primer capítulo de un reciente libro mío «La duda, paradigma de la religiosidad en un mundo plural $»^{16}$, consagrando muchas páginas a este tema-. Aquí solamente añadiré que me agradaría sobremanera que el laicismo, o el pensamiento secular, adoptaran el mismo principio de la duda en la presentación de sus legítimos planteamientos a la estela, por ejemplo, de Amin Maalouf o Edgar Morin.

Creo que en este punto nos encontraríamos Salvador Giner y yo, desde nuestras convicciones y dudas. Estoy seguro de que Giner aceptaría la reflexión del filósofo ateo Comte-Sponville cuando (en un debate con Cazelle, teólogo de Lyon) escribe: «Cazelle y yo no estamos separados más que por lo que ignoramos: ni él ni yo sabemos si Dios existe... aunque él crea en Dios y yo no. Pero estaríamos locos si concediéramos más importancia a lo que ignoramos, y nos separa, que a lo que ya sabemos, tanto él como yo, por experiencia y de corazón, y que nos une..., a saber, la fidelidad común a lo mejor que la humanidad ha producido o recibido» ${ }^{17}$.

15. P. Berger, Los numerosos altares de la modernidad, Salamanca 2016, 144. Hace bien Salvador Giner en dejar de lado el argumentario neo-neurológico a la hora de explicar las vivencias religiosas, por la inmadurez de dicha ciencia hoy. Pero hay muchos fans de la non nata neurología. Un antiguo amigo, en su día devoto fundamentalista de lo transcendente religioso, se ha convertido en no menos devoto cientificista de la nueva neurología.

16. J. Elzo, Morir para renacer.

17. A. Comte-Sponville - H. Cazelles, Dieu, existe-t-il encore?, Paris 2005. 
Con una idea similar concluye Amin Maalouf su discurso, al recibir el doctorado honoris causa que le concedió la Universidad católica de Lovaina: «Disculpen por haber elogiado lo dudoso e incognoscible en un lugar emblemático de la fe y del saber. Pero tengo la debilidad de pensar que, más allá de ciertas apariencias, compartimos algo mejor que las creencias comunes: los valores comunes y una esperanza común ${ }^{18}$.

\section{Lo divino y lo humano. Pero ¿EXISTe lo divino?}

Es evidente que, para el hombre secular, lo divino no existe más allá de lo que, como humanos, decidamos divinizar: algo o alguien. Claro que sin denominarle dios. Ni en singular, ni en plural. Es el término Dios (sobre todo en mayúscula) así como lo divino lo que causa problemas. Aunque el pensamiento secular denominará e incluirá como algo religioso, si no le queda más remedio, tanto lo que ve en el cristiano como en el vegetariano, en el vegano, en el físico culturalista, en el fan absoluto de tal club de fútbol, de tal cantante o grupo artístico o, aunque menos frecuentemente en nuestros tiempos, también lo que ve en tal político o ideología política, sea el socialismo, nacionalismo, marxismo, liberalismo, etc.

Pero si, al menos, reconoce la existencia y uso de las palabras «humano» y «divino», algún sentido habrá de darles. Más que probablemente entenderá lo «divino» como resto y residuo de un tiempo ya felizmente superado o en trance de superación, el largo periodo que nace en la noche de los inicios del tiempo, cual superstición de la sociedad hasta que, inexorablemente, el mundo de la Luces, la llustración con el apoyo de la ciencia, está arrinconando lo divino hasta su previsible, aunque desesperadamente lenta y en nada confirmada, disolución, salvo en colectivos realmente minoritarios, a lo largo y ancho del planeta, y con Europa occidental a la cabeza, impulsada por su intelligentsia en ciencias humanas y sociales (Peter Berger).

Pero ¿cabe hablar de lo divino más allá de lo creado por el hombre (en la concreción que sea, el dios de los cristianos, judíos, musulmanes... el dios fútbol, el dios vegano, el dios patrio, etc.)? ¿Cabe hablar de un Dios -con mayúscula- que nos precede y se nos manifiesta como exterior a nosotros? Es la gran cuestión a la que no creo que pueda darse una respuesta desde la sola razón, pues, por definición, lo que se diga de Dios - para afirmarlo o para negarlo- escapa a los límites de la sola razón, no digamos si se pretende limitar la razón a la razón científico-técnica. El gran Kant, cuando escribió

18. El discurso, titulado Eloge du doute, creo que nunca publicado, me lo dio personalmente Maalouf. Cf. http://amin.maalouf.free.fr/maalouf/texte-001.html. 
sobre la religión, tituló su libro, significativamente, La religión dentro de los límites de la mera razón. Sin haber leído el libro de Kant -aunque sí algunos comentarios especializados-, me atrevo a decir dos cosas: una, que con la mera razón no llegamos a entender lo religioso, y dos, que, sin embargo, con la razón, aun en sus límites, podemos abordar la cuestión religiosa. De tal suerte que los creyentes, aplicando lo que se llama la inteligencia de fe, podamos decir que creer es algo razonable, aunque reconociendo que otros, desde otros parámetros, dirán que desde la razón su creencia consiste en la increencia; ahí estaremos ante el ateo. Otros, desde su razón, dejan la cuestión de la creencia, o de la increencia, en un gran interrogante; y ahí estaremos ante el agnóstico. Aunque sospecho que, en la actualidad, en nuestra sociedad básicamente secular, pero secular de lo religioso transcendente, la mayoría sencillamente pasarán del tema, ni se lo plantearán; ahí estaríamos en el reino del indiferente religioso, pero que resacraliza continuamente otras religiones seculares. En muchos casos, en el sur de Europa occidental, es el tránsito indoloro, luego inconsciente, de la profesión cultural de una religión trascendente a otra, no menos cultural, religión secular.

Volvamos a Calasso para ver que describe lo divino como «aquello que Homo saecularis ha borrado con cuidado e insistencia. Lo ha suprimido del léxico de lo que existe. Pero lo divino no es como una roca que todos ven inevitablemente. Lo divino debe ser reconocido. El reconocimiento es el acto supremo hacia lo divino. Acto aislado, repentino, que no puede trasponerse a un estado determinado. Incessu patuit dea, lo divino es como el paso de una diosa, que avanza y pasa de largo. Lo divino es un centelleo discontinuo, que remite a algo cerrado y continuo. Para Homo saecularis todo esto era evanescente y contrario a la fisiología que había elaborado para sí mismo. Era vano, entonces, dirigir los propios deseos en esa dirección» (p. 51).

Leo y releo este texto magistral. Cada párrafo se presta a mil y un comentarios que tendré el buen cuidado de refrenar. El lector que hasta aquí haya llegado en la lectura de estas tortuosas líneas lo hará a su guisa. Me gustaría, sin embargo, subrayar que lo divino nos es dado no como una roca que no podamos no ver, sino como un centelleo discontinuo y que debe ser reconocido. Lo que exige que no construyamos una fisiología que lo excluya de entrada. Es imposible reconocer lo que se prejuzga que no existe. Sin embargo, quien lea estas líneas desde la cultura bíblica (y desde la fe, con dudas) no puede no pensar en el texto inmenso de Elías en el que constata que Dios se manifiesta en una brisa; o en el primer capítulo del evangelio de Juan, donde se nos dice que «a Dios nadie lo ha visto jamás»; o en Mateo 25, que nos dice que Dios se manifiesta en los otros, particularmente en los necesitados; o, como hemos recordado más arriba, en el texto de Arnoldo Liberman, en 
los otros que nos llevan al Otro; o como nos muestra la Biblia hebraica, en el Dios de Abrahán, en el que nace lo que justamente se denomina la ética judeocristiana, tantas veces prostituida por judíos y por cristianos.

En este orden de cosas, me gusta recordar cómo un día de agosto de 2009, en la Quincena Musical de Donostia - San Sebastián, escuchábamos, levitando (dirigía Gardiner), el oratorio Elías de Mendelssohn. De pronto, leí en la traducción simultánea este texto del libreto que traslado, apenas resumido, aquí. Ante Elías desamparado, que reclama «ver el rostro de Yavé ${ }^{19}$ », el coro canta: «Un viento poderoso que rompía los montes y quebraba las piedras pasó, pero Yavé no estaba en el viento. La tierra tembló y el mar rugió, pero Yavé no estaba en el terremoto. Tras el terremoto vino un fuego, pero Yavé no estaba en el fuego. $Y$ tras el fuego vino un ligero y suave susurro. Y en el susurro vino Yavé» (1 Reyes 19, 10-13). ¡Vaya texto!

¡En el susurro vino Yavé! ¿Y si Dios se manifestara no con truenos y relámpagos, terremotos y fuegos, esto es, no al modo de grandes tratados ni en fórmulas perentorias e impositivas, sino en la insinuación («a Dios nadie lo ha visto jamás», Jn 1, 18; 1 Jn 4), recordará el teólogo y filósofo Maurice Bellet, en un breve pero magnífico libro que leí siendo estudiante, al modo de susurro, «brisa tenue», como traduce Schökel el texto de arriba?

Pero un susurro, una brisa, no se imponen, sino que se insinúan, aunque, para quienes tengan antenas para las zonas de sombra, ese susurro, esa tenue brisa le harán, como poco, levantar la vista y pensar, también con el corazón, un corazón en nada reñido con la razón. No sé por qué asociación inconsciente de ideas, a menudo este tema me traslada a la brevísima aparición de Fricka -apenas cuatro minutos- al inicio del segundo acto de $\mathrm{La}$ Valquiria y que, en realidad, desencadena todo el drama de Wotan y, a la postre, el final del Anillo, del Walhalla y su derrumbe.

En fin, quiero cerrar este punto trasladando unas frases de un libro que leí hace años . Es de Thérèse Delpech. Dice así: «Estas voces hablan de locura, profecía y misterio, temas que han apasionado al espíritu humano durante siglos, pero que ahora, especialmente en los dos últimos siglos, se encuentran en áreas desérticas. Sin haber desaparecido, estrictamente hablando, están enterrados en una memoria colectiva desfallecida, como los recuerdos de los neuróticos, y constituyen lo que Freud habría llamado conjuntos psíquicos que, aunque raras veces atraen la conciencia a sí mismos, no obstante existen y continúan ejerciendo su poder bajo máscaras diversas $»^{20}$.

19. "Yavé»: respeto la grafía del libreto.

20. T. Delpech, L'Appel de l'ombre. Puissance de l'irrationnel, Paris 2010. 


\section{LA INHÓSPITA PREGUNTA DE STUART MILL}

Volvamos a nuestro autor, y en concreto cuando reflexiona sobre una pregunta que se formuló Stuart Mill:

Stuart Mill contó: «Desde el invierno de 1821, cuando leí a Bentham por primera vez, y especialmente desde los comienzos de la Westminster Review, yo había tenido lo que con verdad podría llamarse una meta en la vida: ser el reformador del mundo. Mi concepción de mi propia felicidad estaba completamente identificada con ese objetivo... Solía felicitarme por la certeza de haber encontrado un modo feliz de vivir por haber situado mi ideal de felicidad en algo duradero y distante, en el que siempre cabía realizar algún progreso, sin llegar nunca a agotarlo por haberlo conseguido por completo». Esta situación se mantuvo durante cinco años «a lo largo de los cuales la mejoría general que tenía lugar en el mundo y la idea de que otros y yo estamos entregados a la lucha por promover esa mejoría, me parecía suficiente para llenar de interés y animación mi existencia».

Hasta que un día, continúa Stuart Mill, «desperté de todo eso como de un sueño». ¿Qué había pasado? Había llegado el momento de realizar una pregunta: «Suponte que todas las metas de tu vida se hubieran realizado: que todas las transformaciones que tú persigues en las instituciones y en las opiniones pudieran efectuarse en este mismo instante: ¿sería eso el motivo de gran alegría y felicidad para ti?». Apesadumbrado, Stuart Mill cobró conciencia de que su decidida respuesta a esa pregunta era: ¡No! Entonces experimentó una sensación desconocida y aguda: "Los fundamentos sobre los que había construido mi vida se desmoronaron». De pronto todo era «insípido e indiferente». Siguieron meses de una profunda depresión que abarcó el invierno de 1826-1827. Visto desde fuera, nada había cambiado. Stuart Mill seguía llevando una vida plena de actividad: «Durante ese periodo no dejé de dedicarme a mis ocupaciones usuales... Estaba tan habituado a cierto tipo de ejercicio mental que podía seguir en esa línea incluso cuando el espíritu se había desvanecido. Compuse y pronuncié unos discursos para la Sociedad de Debates. Cómo pude hacerlo y con qué resultado, son cosas que ignoro».

Stuart Mill es considerado todavía hoy una de las luminarias del progresismo. El hecho es que a los progresistas de todas las especies -laicas y religiosas- les faltó siempre la capacidad y la lúcida audacia para hacerse la pregunta que se formuló Stuart Mill en su íntegra honradez, y que lo precipitó a un estado que solo Coleridge supo describir: «Un dolor sin espasmos, vacío, oscuro y desolado» (p. 51-52).

Hasta aquí Calasso. El texto de Stuart Mill es soberbio, de los que invitan a mirar a lo lejos (o sea, dentro de sí) y pensar. ¿Qué echaba en falta Mill? Si su ideal de vida, lograr el progreso de la humanidad hacia una sociedad más justa y feliz, se hubiera cumplido (con su ayuda además), ¿qué más podía esperar? ¿Estaremos ante esa zona de sombra de la que nos hablaba Thérèse Delpech, del poderío de lo que va mas allá de lo meramente racional? Determinada apologética cristiana respondería diciendo que lo que le faltaba a Mill era, digámoslo simplemente, la fe en Dios y la esperanza en la transcendencia. Esta respuesta me parece, además de insuficiente, errónea. 
Al releer el último párrafo de Calasso, algo rechina en mi condición de sociólogo: conozco a más de uno que nunca se ha formulado la pregunta de Mill, de cuya integridad no tengo motivos para dudar y cuyo estado jamás describiré como «un dolor sin espasmos, vacío, oscuro y desolado» (Coleridge). Sin embargo, conozco a más de uno que se han hecho la pregunta de Mill y otras muchas desde su fe, y que, sin embargo, viven en la noche oscura del alma. Por favor, no se concluya que, a fin de cuentas, «la solución pragmática» de poner a Dios entre paréntesis (etsi Deus non daretur) sea la que más oportunidades tenga de no vivir con espasmos, vacío, oscuro y desolado. No. Creo que hay volver a Alfred Schutz y Peter Berger, tal como lo abordo en Morir para renacer ${ }^{21}$. Pero dejemos este punto, clave, para el final. Antes levantemos acta de otras cuestiones que plantea Calasso en su libro y que no hemos abordado en estas páginas.

\section{Para ser completo con Calasso}

Quiero reflejar, aun esquemáticamente, algunas de las ideas que pueblan las últimas páginas del texto de Calasso. En ellas vemos asomar:

-El omnipresente papel de la publicidad en el mundo de hoy.

- La distinción que lleva a cabo Calasso entre secularistas y religiosos, etiquetando a los primeros de turistas y de nativos a los segundos (que también pueden convertirse en terroristas).

-La penetrante reflexión sobre los SBNR (siglas de Spiritual but not religious), uno de los modos de designar a los secularistas en las encuestas de opinión, o en los documentos de afiliación, por ejemplo, en los EE.UU.

-El rechazo a los intermediarios en general, y más en concreto a los ritos y a las representaciones, por parte de los secularistas.

-El papel del movimiento transhumanista y el de la Singularity University en Silicon Valley.

-Al albur de lo anterior, Calasso ofrece unas breves reflexiones sobre los big data y la temática de «los valores» en la era de la inteligencia artificial.

-En fin, vuelve Calasso una y otra vez a determinada concepción de la ciencia como antídoto contra las religiones. Lo hace al final de su ensayo: «Abandonad las religiones por la ciencia, iluminad cada ángulo de lo que queda de lo desconocido, y ya no habrá necesidad de religiones. (La religión es solo un consuelo para aquello que no sabemos)» (p. 83).

Como se comprenderá, cada uno de estos temas nos llevaría a páginas, páginas y páginas de comentarios y reflexiones. Quizá en otra ocasión.

21. J. Elzo, Morir para renacer, 111s. 


\section{ALGUNAS REFLEXIONES FINALES}

De la orfandad de un mundo sin Dios a la guerra de dioses

Un mundo sin Dios nos deja huérfanos. No digo que la humanidad haya de vivir continuamente bajo de la égida de un padre todopoderoso que todo lo ve y todo lo oye (como el Jaungoikoa de nosotros los vascos). Además, ¿qué padre? ¿Yahvé, Alá, Jesús el Cristo, la multitud de dioses que han poblado la condición humana a lo largo de los siglos...? Pero un referente más allá de nosotros mismos nos permite vernos en el espejo de la vida de otra manera, con otra distancia. Es como un hijo ve a su padre (o a su madre) ya en la edad adulta. Parece que los que viven en orfandad echan en falta a sus padres. Dicen.

Pero en realidad el mundo de hoy no vive en orfandad total: ha creado sus dioses o adoptado los que sus congéneres humanos le han ido mostrando, suministrando, proponiendo, si no imponiendo. Parece que los mortales, en su gran mayoría, necesitan algún dios. Así lo revelan los datos del Pew Research Center: apenas llega al $15 \%$ de la población mundial la proporción de quienes se afanan en la vida sin dios (religioso) alguno. Y si no tenemos en cuenta los dioses seculares, la cifra aún se reduciría a un puñado de personas, aunque de estos no hay datos comprobados.

Es posible que el futuro nos depare otra guerra de dioses, cuyas primicias ya están a la vista. Los dioses del mundo secular nos muestran un politeísmo que nada tiene que envidiar al de las civilizaciones griegas y latinas, por limitarme al mundo occidental. Pero, a diferencia de las grecorromanas, los dioses de nuestros días son puramente seculares, no permiten atisbo del «más allá» como Zeus, Júpiter, etc. A lo sumo, aunque en tono menor, un humano casi dios, como el emperador nipón, pero hemos quedado en que nos limitamos al mundo occidental; y si me aprietan las tuercas, al del sureste europeo: España, Francia, Portugal e Italia, con sus diversas regiones (naciones, pueblos, autonomías...) de personalidades bien distintas, unas más marcadas que otras.

\section{Los innumerables dioses de la postmodernidad secular}

Conviene recordar aquí lo ya señalado arriba: que, según Durkheim -luego desde un planteamiento que se quiere científico, en nada religioso-, «un dios, de hecho, es antes que nada un ser que el hombre representa, en cierto modo, como superior a sí mismo y del que él cree que depende. Ya sea una personalidad consciente, como Zeus o Yahvé, o fuerzas abstractas». Así, «la sociedad es (deviene) para sus miembros lo que un dios es para 
sus fieles». Y añade Durkheim: «Debido a que tiene una naturaleza propia, diferente de nuestra naturaleza individual, persigue fines que también son especiales para ella, pero como solo puede alcanzarlos a través de nosotros, busca imperiosamente nuestra ayuda. La sociedad exige que, olvidando nuestros intereses, nos hagamos sus servidores, y nos obliga a toda suerte de incomodidades, privaciones y sacrificios, sin los cuales la vida social sería imposible. Por lo tanto, en todo momento estamos obligados a someternos a reglas de conducta y pensamiento que no hemos construido ni deseado, y que a veces son contrarias a nuestras inclinaciones e instintos más fundamentales» ${ }^{22}$. Con otras palabras, la sociedad, cuando, por representaciones humanas, adviene dios, metastasiada por la conciencia colectiva deviene un dios dictador para la humanidad, su creadora.

¿Cuáles son esas religiones, con sus dioses correspondientes, de la politeísta y secular civilización en la que estamos embarcados en el suroeste europeo, esas religiones que entran en disputa con las religiones trascendentes que ocupan el mismo espacio geográfico, a saber, el cristianismo, el islam y el judaísmo? Son muchas y muy variadas, como en los politeísmos griego y romano. Pero todas seculares, lo repito y remacho. Sin ánimo de exhaustividad y dicho a bote pronto, cabría distinguir diferentes ámbitos de nuestra vida en los que construimos dioses o aceptamos, cuando no adoptamos, los que han construido nuestros congéneres:

-Las del ámbito de ideología política. Así nacerían determinados nacionalismos, socialismos, liberalismos, patriotismos, etc., y ya en su fanatización los comunismos, fascismos, etc., como modelos y reglas de comportamiento para una pretendida sociedad mejor.

-Las divinizaciones de pueblos, naciones, colectivos, sociedades, etc., que a la postre nos darán el «American first», «Deutschland über alles», «Les Français d'abord», «Todo por la patria», «Euskadi ala hil», etc.

-En nuestro mundo occidental, en el que hemos transitado desde la religión del espíritu hacia la religión del cuerpo, este, el cuerpo, es uno de los dioses de la actual civilización: la OMS es, en el mundo secular occidental, el equivalente, en el estado de cristiandad, al Vaticano. Es la OMS quien nos dicta (con capacidad, luego poder coercitivo, como el Vaticano en la era de la cristiandad) las normas de conducta. Si el objetivo final de la era de la cristiandad era la vida eterna en el cielo, el de la OMS es el de una larga vida en la tierra, procurando despedirse de la misma lo más tarde posible y con un cuerpo lo más sano posible. El cielo (o el infierno, si se peca contra las normas de la OMS) está aquí, no allá. De ahí que, en el pensamiento secular,

22. E. Durkheim, Les formes élémentaires de la vie religieuse, 295-296. 
nadie tenga miedo a lo que le sucederá después de la muerte, sino en cómo llegará a la muerte. De ahí la apuesta, cada día mas firme, por el suicidio asistido (con un nombre más bonito y embaucador por encubridor, claro).

-Para la divinidad «salud» de nuestros días, la moral se reduce, en última instancia, a dos grandes mandamientos, dándose los demás por añadidura: no fumar y estar delgado, quedando los fumadores (principalmente) y los gordos como los proscritos de la sociedad de la salud. Además, al igual que en la ley mosaica, el sacrificio tiene más valor que el placer.

-En este orden de cosas, cada día para más personas la alimentación «sana» se convierte en un objetivo divinizado: así nace el mundo vegetariano, que se presenta sin recato alguno como un mandamiento en determinadas religiones, divinas y seculares. Más recientemente el mundo vegano. De ahí la proliferación de tiendas y culturas «bio», y de la alimentación «sin» (sin grasas, sin azúcar, sin sal, sin alcohol, sin... sin... sabor). Aunque no hay que olvidar el pecado de la gula en el universo cristiano.

-Algunos deportes. Respecto del fútbol, leí de un pensador inglés, cuyo nombre he traspapelado, que «algo de mucho calado le debe faltar a muchos ingleses cuando para ellos el fútbol es tan importante en sus vidas». Y no solamente para los ingleses. Ya he comentado más arriba la increíble importancia que le concedió la prensa francesa a la victoria del equipo de Francia en el mundial de fútbol de 2018. Y las páginas y páginas, horas y horas de radio y televisión dedicadas en España a «la roja», y los dimes y diretes acerca del cambio de entrenador a dos días del inicio del Mundial. El fútbol con la televisión, comandados por la omnipresente publicidad que impone que no pueda haber dos partidos de primera división a la misma hora y día de la semana, muestra, a quien quiera verlo, el inmenso poder de uno de los dioses más importantes y poderosos del politeísmo del mundo de hoy: el dios Dinero, cual becerro de oro contemporáneo.

-Uno de los mecanismos -iy qué mecanismo!- del que se sirve el dios Dinero y la diosa Publicidad es la implantación de los big data y de su control por los amos del mundo, muchos de los cuales se cobijan bajo el acrónimo de Ios GAFA: Google, Amazon, Facebook y Apple. No solamente saben todo (lo que les interesa) de nosotros, sino que además somos nosotros los que les proporcionamos nuestros datos. Gratuitamente, cuando no, para más inri, pagando mientras se los damos. Nunca dios alguno recibió tanta pleitesía. Y nunca dios alguno ganó tanto dinero como los «gurús» de los GAFA.

-En fin, podría seguir con otros ámbitos de las divinidades de la sociedad moderna: la moda; el culto al ocio (que viene de lejos con el panem et circenses romano y, antes, griego); el alcoholismo y la drogadicción, convertidos en falaces dioses de liberación que, en realidad, esclavizan; la terrorífica 
dictadura digital, y la pasión por castigar y demoler inmisericordemente a personas con responsabilidades públicas, cual dios sádico, omnisciente y omnipotente; las personas deificadas en el campo del deporte, de la música, etc.

En este universo de múltiples divinidades seculares, bajo el imperio cada día más extendido y apremiante de la civilización secularista, es en el que han de habérselas las divinidades religiosas que han imperado en el planeta hasta ayer mismo. Y, se diría que han de habérselas en competición, competición del que, como en algunos partidos de fútbol, salen de entrada como perdedores. Aunque como en esos partidos, a menudo hay sorpresas. ¿Quién apostó al inicio del mundial de 2018 a que Croacia llegaría a la final, mientras que grandes favoritas como España, Alemania y Brasil no llegaron ni a las semifinales? Pero tampoco caigamos en la ciencia ficción (como en el creciente mundo de las apuestas en el fútbol: otra vez el dios Dinero) con el futuro de las religiones religiosas en su «competición» con las religiones seculares. Al lector interesado en cifras le sugiero que se asome a los trabajos del Pew Research y a sus proyecciones para el año 2050. Aunque sin olvidar la capital importancia de pensar y formularse las buenas preguntas, las preguntas de siempre: ¿quién soy yo?, ¿de dónde vengo?, ¿hay un más allá?, ¿por qué he de hacer el bien y no el mal?, ¿hay una cosmovisión holística que ayude a mi plenitud humana, sea en la forma inmanente o con apertura a la trascendencia?, ¿y qué trascendencia?, ¿trabajar para sí mismo es el camino hacia la felicidad, o no será más fiable (y rentable) el camino de la alteridad, trabajar para el otro, con el otro, y establecer así poco a poco un universo más fraterno y convivial?, etc.

\section{Superando el binomio sagrado-secular}

Con mis lecturas, reflexiones y escritos llevo varios años tratando de superar el pensamiento binario. El pensamiento binario es una forma mental que nos hace dividir, separar, poner en oposición los conceptos, las ideas, los valores, las necesidades y los sentimientos, en vez de conjuntarlos, hacerlos vivir en cohabitación, en colaboración, mediante una forma de pensar complementaria y comprensiva. El pensamiento binario destaca las fórmulas «sea-sea», «aut-aut», en lugar de «et-et».

Hay muchos casos en los cuales aplicamos este modelo en nuestra forma de pensar, escribir y actuar. Así llegamos al dualismo, que no es sino una resultante del pensamiento binario, el cual es incapaz de definir las cosas como realidades complejas, como lo son la inmensa mayoría de las realidades, y busca monocausalidades. Poco importa que el problema sea complejo, digamos el inicio de la primera guerra mundial, el crash bursátil de 2008, etc. 
El pensamiento binario forma parte de nuestra vida cotidiana y, a poco que no estemos vigilantes, conforma nuestras estructuras de pensamiento y nuestros juicios morales. He aquí algunos ejemplos de pensamiento binario muy extendidos entre nosotros que, si bien nos ayudan a ordenar la mente, si no sabemos superarlos y, sobre todo, si nos quedamos con un solo polo del pensamiento binario, nos deformarán el juicio y el comportamiento. Pienso en lo innato y lo adquirido; lo privado y lo público; el espíritu y el cuerpo; jóvenes y viejos (dicho con corrección política, personas mayores); individuo y grupo; clases superiores e inferiores; naturaleza y cultura; instinto e inteligencia; corazón y razón; sexo y género; nacionalismo e internacionalismo; progresistas y conservadores; transhumanistas y bioconservadores; soberanistas y mundialistas; localistas y transfronterizos; enraizamiento y emancipación; ateo y creyente; inmanencia y trascendencia... Y obviamente, en el par binario sagrado versus profano, o en el par religioso versus laico.

A este tema le he consagrado el segundo capítulo de mi libro Morir para renacer, ya referenciado. Acudiré a algunas reflexiones de esa publicación en las páginas que siguen, con algún añadido posterior.

Así, Jean Duchesne, escribiendo sobre la pertenencia a la Iglesia católica, dirá que «se es católico y más cosas», que «ser católico no es 'todo' o 'nada'», dando a entender que ser católico no solo no equivale a entrar en un mundo cerrado, en un gueto, sino que la dimensión de la fe católica no agota la totalidad de la experiencia vital y cotidiana de una persona ${ }^{23}$.

Peter Berger, en su ya citado Los numerosos altares de la modernidad, escribe que, para la gran mayoría de quienes se dicen creyentes religiosos, su fe y su vida secular no se presentan como formas de ser y actuar antagónicos, como «dos modelos mutuamente exclusivos de atender a la realidad» (p. 107), no es una disyuntiva «aut-aut» (esto o aquello), sino una cópula «et-et» (esto y aquello). Esta simple idea es clave. La superación del par binario «religioso versus secular», entre los creyentes, se logra cuando reconocemos en nuestra vida que ambas realidades no son antagónicas, sino dos dimensiones entrelazadas en su propia unicidad, conformando la totalidad de la persona, creyente en este caso. Lo tienen más complicado los «no creyentes totales», el homo saecularis de Calasso, pues, de entrada, ya han excluido hasta la posibilidad de lo sagrado. Aquí se aprecia la gran diferencia entre el ateo y el agnóstico.

En su artículo «Breve defensa de un agnóstico», lo dice así Hans Enzensberger: «Para mí el ateísmo no es una opción, sino una idea fija. No quiero pertenecer a ese club. En general, me cuesta decidirme por una filiación...

23. J. Duchesne, Le Catholicisme minoritaire? Un oxymore à la mode, Paris 2016, 86s. 
Así pues, solo me queda una posibilidad, a saber: ser y seguir siendo agnóstico... El agnosticismo tiene numerosos pros y contras. Te permite moverte con mayor libertad y no tienes que someterte a toda clase de preceptos concebidos por cualquier institución. Desprenderse de la disciplina del partido o la Iglesia en cuestión puede ser un alivio, más si se trata de las trabas de una ideología política. El inconveniente reside en que el agnóstico no acaba de pertenecer a nada» (El País, 5.7.2018). Por eso no son legión, aunque no falten, sobre todo entre los intelectuales que tengan a gala ser versos sueltos; ni patriotas ni religiosos: justamente homo saecularis, que diría Calasso, aunque respetuosos de creyentes y patriotas que no estén fanatizados ${ }^{24}$.

Volvamos a Peter Berger. Escribe:

¿Goza el discurso secular de una posición privilegiada en la mente de las personas? Sí, sin duda alguna. ¿Es excluyente? En algunos casos sí, por lo general no. Y es aquí donde, tanto los teóricos de la secularización como sus críticos han cometido un error. Al principio formé parte del primer grupo y luego me uní al segundo, pero ambos sobrevaloran la coherencia de la conciencia humana. En la experiencia de la mayoría de los individuos, la secularidad y la religión no son contradictorios entre sí. Antes bien, coexisten, perteneciendo cada una de ellas a una forma particular de contemplar la realidad. A decir verdad, hay algunos individuos que son completamente religiosos o completamente seculares, por ejemplo, un staretz ruso que práctica sin cesar «la oración de Jesús», o un profesor de sociología sueco que rechaza cualquier atisbo de transcendencia como una superstición residual. Esos dos casos tal vez sean interesantes, pero representan a una minoría relativamente pequeña de la población mundial, distribuida de forma diversa en las distintas regiones del mundo ${ }^{25}$.

Creo que este párrafo retrata muy bien el fondo del pensamiento de Berger en este libro sobre «los numerosos altares de la modernidad». Personalmente, creo que lo que él llama «coherencia humana» en realidad sería complejidad de la conciencia humana, que el mismo Berger subraya sirviéndose del pensamiento de Alfred Schutz, que explicita en las páginas siguientes y que presento sucintamente a continuación, por su gran pertinencia.

En una de sus publicaciones, Schutz (sin hacer mención alguna a la cuestión religiosa) sostiene que la conciencia de un individuo no es un todo coherente, sino que consta de lo que él llama «realidades múltiples» ${ }^{26}$. Schutz acuñó dos expresiones: "la realidad cimera», que Berger traduce como «la realidad de la vida cotidiana», y «las provincias finitas de sentido»,

24. En ese orden de cosas, cf. Amos Oz Queridos fanáticos, Madrid 2018.

25. P. Berger, Los numerosos altares de la modernidad, 108.

26. Berger referencia este texto de A. Schutz, On Multiples Realities: Philosophy and Phenomenological Research 5/4 (1945) 533-576. 
que Berger traduce como «realidades a las que escapamos desde la realidad cimera. Son finitas porque casi siempre son temporales; entramos en ellas al abandonar la realidad cotidiana y son reales mientras duran, pero quedan atrás cuando retornamos a la vida cotidiana» (p. 111). Lo que no quiere decir, en absoluto, que no pueda tener incidencia en la vida cotidiana. A veces tan fuerte que puede cambiar la vida de una persona.

Peter Berger traslada la distinción de Schutz a la experiencia religiosa. Así refiere a Max Weber cuando, hablando de la religión, distinguía entre «la religión de las masas», esto es, la experiencia religiosa cotidiana de una persona ordinario que está en la realidad de la vida cotidiana y que no experimenta grandes emociones, frente a lo que llama Max Weber «los virtuosos de la religión», que tienen una experiencia mucho más intensa y que cruza el umbral de lo cotidiano adentrándose en otra realidad distinta ${ }^{27}$. ¿En qué realidad? Berger, como hiciera Calasso, y páginas arriba lo hemos mostrado, se refiere a Rudolf Otto, cuando el gran fenomenólogo describe esta realidad de intensidad religiosa como totaliter aliter (totalmente otra, diferente), como una experiencia más allá de lo ordinaria, me atrevo apostillar. Berger indica que los grandes místicos son los que ofrecen prototipos de esa vivencia. Y en este contexto alude a Teresa de Ávila con estas palabras: «Teresa de Jesús tuvo experiencias extáticas en las que se difuminaba el mundo cotidiano y solo Dios era real. (...) Sin embargo, Teresa tenía que cambiar de realidad cuando salía del éxtasis y debía ocuparse de los libros de cuentas de su orden de monjas. Incluso tenía que gestionar la coexistencia en su conciencia de su realidad mística y del discurso secular que gobierna la realidad de la vida mundana» ${ }^{28}$.

La socióloga Nancy T. Ammerman, en su «Respuesta» al texto de Berger en el libro Los numerosos altares de la modernidad ${ }^{29}$, basándose en uno de sus trabajos, lo dice con estas palabras: «En el ámbito de la salud, la mayoría de la gente relataba sus esfuerzos por comer de modo adecuado y mantenerse sanos, guiados completamente por la educación y la ciencia secular. Por otro lado, sus respuestas a las enfermedades graves y a la muerte estaban a menudo colmadas de oración y de la presencia espiritual. Tal

27. No se entienda «religión de las masas» como la de los miembros de una sociedad que estuvieran situados en lo bajo del escalafón social o cultural. En realidad, se trata de diferenciaciones carismáticas de las personas. Algunas, las "virtuosas», las alcanzan en grado sumo (chamanes, ascetas, grandes místicos, etc.), siendo la religión de las masas la de quienes no están particularmente dotadas para el carisma religioso.

28. P. Berger, Los numerosos altares de la modernidad, 112.

29. El libro de Berger no concluye con su sola aportación, sino que hay tres «Respuestas» críticas a sus planteamientos sumamente interesantes, redactadas por tres eminentes sociólogos: D. Pollack, N. Ammerman y F. Yang. 
vez donde mejor se vean los estados múltiples de la realidad y los distintos relatos es en la persona que reza para que Dios guíe la mano del doctor ${ }^{30}$. Evidentemente, se puede rezar para librarse de una enfermedad y a la vez acudir al médico. Lo hacen los creyentes.

Pero Ammerman va más lejos, y propone una tesis que, como poco, tiene la doble virtualidad de llamar la atención y de hacer pensar. Escribe en su «Respuesta»: «Berger describe la presencia de múltiples realidades seculares y sagradas como un 'cambio de código'. Sin duda resulta apto, pero sospecho que puede establecer una distinción demasiado tajante entre los códigos y los campos a los que pertenecen. A veces la gente es consciente de que pasa de uno a otro, pero muy a menudo parecen ocupar un espacio único que es a la vez mundano y sagrado. No se trata de que nuestra realidad fundamental intrínseca sea secular, mientras que el mundo que elegimos en el exterior pueda ser religioso si así lo decidimos. Más bien estoy convencida de que la mezcla de lo sagrado y lo secular se parece más al Spanglish que al bilingüismo» ${ }^{31}$.

Spanglish o bilingüismo, esto es, ¿mezclamos los códigos o los diferenciamos? Personalmente, diría que las dos cosas. Creo que mucho depende de la circunstancia en la que ambos códigos operan en la persona de matriz religiosa. Si se enfrenta a una enfermedad grave, muy probablemente lo secular y lo religioso se mezclen, como el Spanglish. Pero si estamos ante un investigador social, mientras analiza, por ejemplo, la religiosidad de un colectivo social, actuará (o intentará actuar) poniendo entre paréntesis sus creencias, mientras que ese mismo investigador social, en una eucaristía, pondrá (o intentará poner) entre paréntesis su dimensión de investigador social para unirse a la oración de la comunidad. Luego diferenciará los dos planos ${ }^{32}$.

De hecho, una cuestión recurrente, ya en los clásicos de la sociología de la religión, es la constatación de que la religión trata de lo ordinario y lo extraordinario. Ya lo vemos en Max Weber, en sus estudios sobre el carisma, cuando se pregunta cómo traducir en la vida ordinaria el extraordinario carisma del fundador. Como escribe Olivier Bobineau, «podemos decir que el acto religioso se refiere principalmente a la manera de vivir cada día de lo

30. N. T. Ammerman, Sacred Stories Spiritual Tribes: Journal for the Scientific Study of Religion 52/2 (2013) 258-278; ver las conclusiones.

31. P. Berger, Los numerosos altares de la modernidad, 195.

32. Admito, sin dificultad alguna, el carácter un tanto exagerado de la diferenciación entre las dos actitudes del mismo investigador social, de matriz religiosa, en su gabinete de trabajo y en la eucaristía. En ambos casos por la dificultad de poner entre paréntesis sus dos almas, la de creyente en su gabinete de trabajo, la de científico social en la eucaristía, particularmente en las homilías. 
que ha sido o es extracotidiano. Básicamente, el acto religioso hace ordinario con lo extraordinario, y extraordinario con lo ordinario ${ }^{33}$.

Cierro estas excesivas páginas con unas palabras que escuché el 8 de agosto de 2018 a Gerard Defois, arzobispo emérito de Lille, en un coloquio que seguí con gran atención en la iglesia Saint Laurent de Kanbo (Cambo les Bains). Intervinieron, además de Defois, Michel Camdessus, Jean-Baptiste de Foucauld y Alain Lamassoure. El título del coloquio rezaba así, traducido al castellano: «¿Hacia qué mundo nos dirigimos? ¿Con qué Europa? ¿Con qué Iglesia?».

Entre otras ideas, el arzobispo de Lille afirmó que «en la Iglesia estamos viviendo una transformación cultural de pertenencia social creyente por herencia sociocultural hacia un proceso de 'conversión' más individual y emocional». Estamos dejando atrás el cristianismo sociológico por el cristianismo de convicción y, citando al papa Francisco, afirmó que «hay que pasar de una pastoral de encuadramiento a otra pastoral de acompañamiento».

Siguiendo el tema del coloquio, Defois reflexionó sobre Europa desde el cristianismo. Entre otras ideas subrayo aquí estas:

«Pensar Europa como una comunidad de recursos y no como un capital de raíces cristianas históricas».

«Pensar Europa como una confluencia de espiritualidades históricas, como un espacio de religiones (Asís, 27 de octubre de 1986 es el prototipo), llamado a expresar la salvación del hombre en su historia», pues, "en Asís, se ha proyectado una plataforma de solidaridad que libera al sujeto del totalitarismo tecnocrático o ideológico (que invade nuestro mundo moderno), y abre perspectivas de recepción del Otro, en busca de la verdad interna».

Comenzó su intervención con una frase para no olvidar (no es textual, tomada de mis notas, pero creo trasladar fielmente su pensamiento): «La religión no es como una cataplasma que se aplica a una sociedad enferma. La religión también forma parte de esa misma sociedad, supuestamente enferma». Lo sagrado y lo profano juntos, aunque no siempre revueltos.

33. O. Bobineau, Sociologie religieuse, en Encyclopedie Universalis, 2017. 